\title{
FACTORS AFFECTING THE REPURCHASE INTENTION OF E-COMMERCE CUSTOMERS IN SHARING ECONOMY ACTIVITIES
}

\author{
Warniancy Ariesty ${ }^{1)}$, Ridho Bramulya Ikhsan ${ }^{2)}$ \\ ${ }^{1,2)}$ Management Department, BINUS Online Learning, Bina Nusantara University, Jakarta, Indonesia \\ Corresponding author: ridho.bramulya.i@binus.ac.id
}

\begin{abstract}
The sharing economy is a peer-to-peer activity where people can obtain, provide, or share access to goods and services facilitated by a community-based online platform. However, transaction activities in $e$ commerce platforms frequently result in many issues, including a lack of security for customer privacy data, fraud, and other risks that reduce consumers' willingness to make repeat purchases in e-commerce. The purpose of this study was to determine the factors that affect repurchase intentions, such as information quality, transaction security, and trust. Quantitative methods are used to solve the hypothesis. The research data was collected employing a questionnaire distributed to 160 customers who had shopped on the ecommerce platform. Questionnaire data were analyzed using PLS-SEM. The results indicate that the quality of information and transaction security has a positive and significant effect on trust, and trust has a positive and significant impact on repurchase intentions in e-commerce.
\end{abstract}

Keywords: Sharing Economy, E-Commerce, Information Quality, Transaction Safety, Repurchase Intention

\section{Introduction}

Information and communication technology impact everyday life (Pauzi, Thoo, Tan, Muharam, \& Talib, 2017). It can also change the perspective of the purpose of transactions to encourage the emergence of collaborative consumption. Individuals provide goods and services to each other through online intermediaries (Chen \& Chang, 2018). Buyers and sellers can benefit from collaborative consumption by lowering transaction costs (Hansen Henten \& Maria Windekilde, 2016). This concept has spread rapidly in online social networks, thereby generating economic benefits and accelerating the development of the sharing economy (Chen \& Chang, 2018).

Selling through an e-commerce platform is one of the sharing economy systems. Prior researchers explained that the volume of purchases delivered via the internet has an immense value. The impact is that companies are aware of new potential for implementing e-commerce (Skordoulis, Kaskouta, Chalikias, \& Drosos, 2018).

The results of the e-commerce survey from the Indonesian Central Statistics Agency (BPS) in 2020 show an increase in the number of new businesses every year. $71.18 \%$ of businesses started selling through the internet in the last three years. From 2010 to 2016, 26.90\% started businesses by selling online, and $1.92 \%$ of businesses started before 2010. This condition indicates that the e-commerce market in Indonesia is very massive and prospective because it is supported by an increasing number of internet users active in Indonesia.

This phenomenon provides enormous opportunities in various fields, including the economic domain and challenges for individuals, organizations, and society. The younger generation prefers interacting and transacting via the internet rather than meeting face-to-face because it is more effective and efficient. It is undoubtedly a big challenge for conventional entrepreneurs to switch to e-commerce. Through e-commerce, entrepreneurs, both small and large, compete to attract and influence consumers to choose their products considering the very competitive competition. Trading activities on e-commerce platforms frequently result in many issues, including customer privacy, data security, fraud, and other risks. As a result of the lack of physical contact between the seller and the buyer, building trust in an offline business is more accessible than online (Cheung \& To, 2017).

Consumer trust is one of the main factors shaping repurchase intentions, and this factor is the most crucial goal for the company's success to survive in competition. In addition, information quality and transaction security factors can create a sense of trust in buying and selling activities. This study analyzes the information and transaction security rate in shaping consumer trust, impacting repurchase intentions in ecommerce settings.

\section{Literature Review \\ Sharing Economy}

The development of the internet has facilitated the emergence of a large-scale sharing economy, effectively amplifying the economic surplus into an easy-to-navigate platform for matching the supply and demand of products and services on a global scale. It generates new economic benefits while addressing inefficiencies caused by financial surpluses (Chen \& Chang, 2018). 
The sharing economy is a platform explicitly oriented towards smartphone users, and users can access sharing economy services from anywhere using mobile applications (Ganapati \& Reddick, 2018). According to Kian, Loong, and Fong (2018), the internet has created a window of opportunity for people worldwide to communicate without space and time constraints, allowing everyone to conduct viable and direct business opportunities through virtual platforms. The internet has distinct advantages: low search costs, simple price comparisons, time savings, and an infinite variety (Ahmad \& Callow, 2018).

Companies with a sharing economy system use an internet platform that provides the technological infrastructure to exchange, interact, communicate, and participate within the network. Because it brings together various producers and consumers, this platform is multifaceted. The platform's primary function is to serve as a conduit for exchanging goods and services between groups (Evans \& Schmalensee, 2016).

\section{Information Quality}

Information quality refers to the extent to which a system provides valuable and significant information to users in a timely and accurate manner (Zhao, 2019). According to Ranganathan and Ganapathy (2002), the primary determinant of website quality is information quality. The most basic form of communication between online buyers and sellers is information quality, a critical factor in establishing trust (Kim \& Park, 2013). (Li \& Lin, 2006) explained that the quality of information includes accuracy, timeliness, completeness, and credibility of the exchange of information. Lee, Sung, and Jeon (2019) added that the quality of information could be measured through accurate information, reliable information, information with the right level of detail, and information in an appropriate format.

The instruments used to measure information quality in this study are the accuracy of information (accuracy), the ability to provide current and timely information (timeliness), completeness of the information (fullness), the ability to provide reliable information (credibility), and presentation of information that is easy to understand (format).

\section{Transaction Safety}

Consumers work hard to safeguard the privacy and security of their personal information collected during offline and online transaction processing. The online environment is more dangerous than the traditional business environment (Featherman \& Hajli, 2016). According to Kong, Wang, Hajli, and Featherman (2020), transaction security is also critical in the sharing economy. For example, an active customer on an ecommerce platform considers using the platform because of the secure payment system and risk evaluation provided before a transaction is confirmed so that it can help to investigate suspicious payments or orders. Users need a high level of security and transaction privacy related to transactions. When consumers provide bank account information when making a payment, they put themselves at risk. The platform's strong transaction security can boost customer trust (Kim \& Park, 2013).

Transaction security can be measured through security measures to protect users, verify user identities, ensure transaction-related information is protected during transactions, feel secure using electronic payment systems (Kong et al., 2020). Thus, the high level of transaction security in the sharing economy platform can increase user confidence.

\section{Trust in E-Commerce}

The sharing economy concept is not new, and what is novel is trusting technology to support the sharing economy. Having secure financial transactions online, using technology without being exploited, and facilitating secure transactions are all examples of trust in technology as a security concern related to protection from harm (Dillahunt \& Malone, 2015). When customers make online transactions, trust is crucial in eliminating uncertainty or uncontrollable capacities (Zhu, Mou, \& Benyoucef, 2019). Customers cannot believe they are completely safe from security risks such as uncertainty in transactions and personal information. However, the more satisfied a customer is, the more he trusts the e-commerce service platform's security (Choi \& Mai, 2018).

The customer's trust in the seller depends on reliable actions that significantly affect the customer's intention to buy online. Furthermore, Oliveira, Alhinho, Rita, and Dhillon (2017) explain that the primary source to increase overall customer trust is that the seller must have competence, integrity, and benevolence that the customer can feel. Tam, Loureiro, and Oliveira (2020) assess trust in several ways, including overall confidence, trust in transactions, and trust in virtue.

\section{Repurchase Intention}

Repurchase intention is a consumer's decision to choose a brand to buy something and ignore other options (Trivedi \& Yadav, 2018). By enhancing the influence of customer engagement on repurchase intent, research conducted by Lim, Cheah, Waller, Ting, and Ng (2020) provides empirical support for the notion that business actors on e-commerce platforms seek to entice customer repurchase interest should concentrate on developing effective strategies for engagement. The study reveals that trust, responsiveness, reliability, and compatibility influence customer engagement, determining repurchase intentions in the sharing economy. 
Consumer repurchase intention is one component of consumer loyalty, defined as a consumer attitude that retailers prefer (Choi \& Mai, 2018). Marketers and researchers must understand consumers' desire to repurchase (Yang, Van Ngo, Chen, Nguyen, \& Hoang, 2019). Adapted from Wang and Chu (2020), a fouritem scale was used to assess repurchase intent, namely the probability of considering a repurchase, considering a repurchase, the likelihood of repurchasing, and being willing to repurchase.

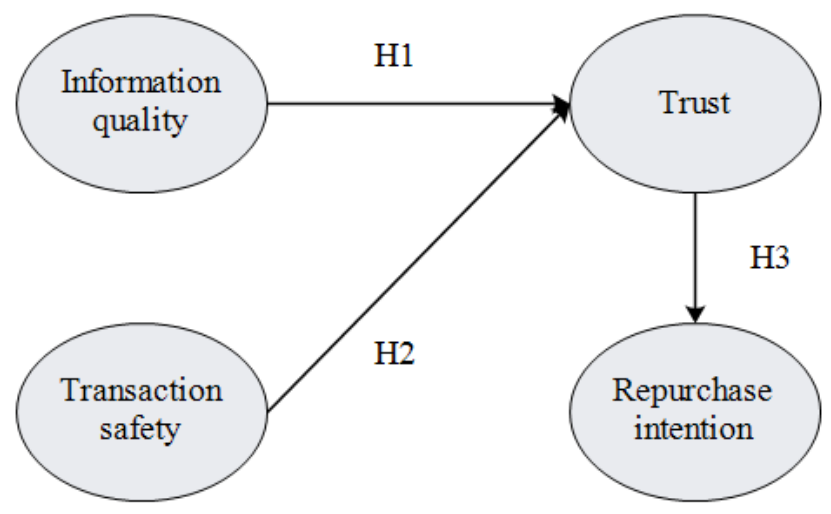

\section{Hypothesis}

Figure 1. Research Framework

Based on the background description, the following is the research hypothesis.

H1: information quality has a positive and significant effect on trust.

$\mathrm{H} 2$ : transaction safety has a positive and significant effect on trust.

H3: Trust has a positive and significant effect on repurchase intention

\section{Research Methods}

This study uses quantitative methods, with the type of research used being causal research. The sample size in this study is determined using Hair, Hult, Ringle, and Sarstedt's (2017) approach, namely the number of indicators of all variables multiplied by 5 to 10 . There are 16 total indicators, so that the minimum sample size is 160 , namely consumers who have shopped online through e-commerce. The sampling technique used is convenience sampling which is included in the non-probability sampling (Hair, William C, Barry J, \& Rolph E, 2019). The data collection technique used a questionnaire with a semantic differential scale measurement scale. Respondents' answers to the questionnaire items were processed and analyzed using PLS-SEM (Hair et al., 2017) with SmartPLS 3.3 software (Ringle, Wende, \& Becker, 2015)

\section{Result and Discussion}

\section{Characteristics of respondents}

Gender, age, monthly income, and frequency of e-commerce shopping in 1 month were used to categorize respondents in this study. According to Table 1, the characteristics of the respondents are dominated by women aged 21-29 years with a monthly income ranging from Rp 5.000.001 to Rp 10.000.000. E-commerce purchases are made 11-20 times per month.

Table 1. Characteristics of respondents

\begin{tabular}{llcc}
\hline Characteristics & & Frek. & Percentage \\
\hline Gender & Male & 54 & $34 \%$ \\
Age & Female & 106 & $66 \%$ \\
& $<20$ & 14 & $9 \%$ \\
& $20-29$ & 93 & $58 \%$ \\
& $30-39$ & 32 & $20 \%$ \\
Monthly Income & $40-50$ & 17 & $11 \%$ \\
& $>50$ & 4 & $3 \%$ \\
& $<$ Rp 5.000.000 & 38 & $24 \%$ \\
& Rp 5.000.000-Rp 10.000.000 & 87 & $54 \%$ \\
Monthly Purchase Frequency & Rp $10.000 .001-$ Rp 20.000.000 & 24 & $15 \%$ \\
& Rp 20.000.001 - Rp 30.000.000 & 8 & $5 \%$ \\
& $>$ Rp 30.000.000 & 3 & $2 \%$ \\
& $<10$ & 42 & $26 \%$ \\
& $10-20$ & 91 & $57 \%$ \\
& $21-30$ & 18 & $11 \%$ \\
& $>30$ & 9 & $6 \%$ \\
\hline
\end{tabular}




\section{Outer Model}

The PLS-SEM analysis produces two measurements: the outer and inner models (Hair et al., 2017). The extreme model is used to assess the instrument's validity and dependability. Table 2 shows the results of the outer model. The loading factor indicator value for each variable is more significant than 0.7 (Hair et al., 2017). Likewise, the average variance extracted (AVE) value is more important than 0.5 (Hair et al., 2017). This value indicates that the convergent validity is very satisfactory. The reliability test refers to the Composite Reliability (CR) and Cronbach Alpha (CA) values. As a result, each variable has a CR and CA value of more than 0.7 so that the indicators used to measure each variable have a high level of consistency.

Table 2. Loading Factor, AVE, Composite Reliability and Cronbach's Alpha Test

\begin{tabular}{lccccc}
\hline \multicolumn{1}{c}{ Variable } & Item & Loading Factor & AVE & CR & Cronbach's Alpha \\
\hline Information & IQ.1 & 0.805 & 0.697 & 0.920 & 0.891 \\
Quality & IQ.2 & 0.862 & & & \\
& IQ.3 & 0.888 & & & \\
\multirow{4}{*}{ Transaction Safety } & IQ.4 & 0.821 & & & \\
& IQ.5 & 0.796 & & & \\
& TS.1 & 0.701 & 0.597 & 0.855 & \\
& TS.2 & 0.843 & & & \\
Trust & TS.3 & 0.716 & & & 0.854 \\
& TS.4 & 0.821 & & & \\
Repurchase & TR.1 & 0.842 & 0.774 & 0.911 & \\
Intention & TR.2 & 0.894 & & & \\
& TR.3 & 0.902 & & & \\
& RI.1 & 0.854 & 0.586 & 0.849 & \\
& RI.2 & 0.740 & & & \\
\hline
\end{tabular}

Furthermore, the discriminant validity test used the Heterotrait-Monotrait Ratio (HTMT) method (Henseler, Ringle, \& Sarstedt, 2015). Table 3 demonstrates that the correlation value between constructs is less than 0.9 , indicating that discriminant validity is satisfactory.

Table 3. Discriminant Validity - HTMT Ratio

\begin{tabular}{lcccc}
\hline \multicolumn{1}{c}{ Variable } & Information Quality & Repurchase Intention & Transaction Safety & Trust \\
\hline Information Quality & & & & \\
Repurchase Intention & 0.607 & & & \\
Transaction Safety & 0.854 & 0.601 & & \\
Trust & 0.779 & 0.634 & 0.846 & \\
\hline
\end{tabular}

\section{Inner Model}

The inner model in this study is to evaluate the estimated value of the path coefficient and the significance value of the relationship between variables, namely the relationship between information quality and transaction safety with trust, then trust with repurchase intention.

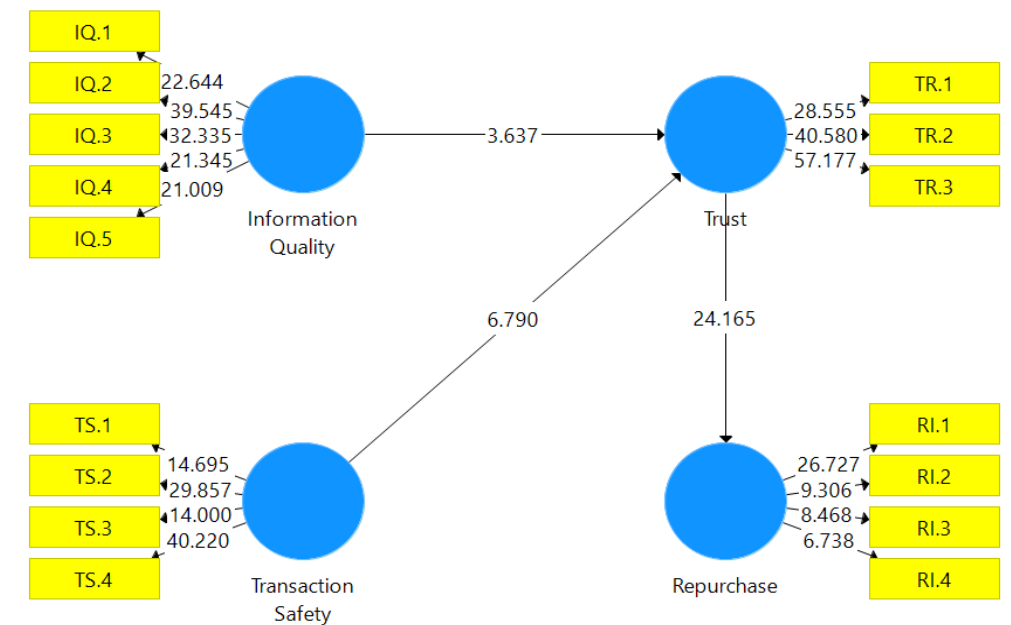

Figure 2. Inner Model 
Table 4. Hypothesis Testing

\begin{tabular}{|c|c|c|c|c|c|c|}
\hline \multirow[t]{2}{*}{ Path } & \multirow{2}{*}{$\begin{array}{l}\text { Original } \\
\text { Sample }\end{array}$} & \multirow{2}{*}{$\begin{array}{l}\text { Standard } \\
\text { Deviation }\end{array}$} & \multicolumn{2}{|c|}{$\begin{array}{l}\text { Confidence Intervals } \\
\text { Bias Corrected }\end{array}$} & \multirow{2}{*}{$\begin{array}{c}\mathrm{T} \\
\text { Statistics }\end{array}$} & \multirow[t]{2}{*}{ P Values } \\
\hline & & & $2.5 \%$ & $97.5 \%$ & & \\
\hline Information Quality $\rightarrow$ Trust & 0.332 & 0.091 & 0.158 & 0.512 & 3.637 & 0.000 \\
\hline Transaction Safety $\rightarrow$ Trust & 0.498 & 0.073 & 0.341 & 0.629 & 6.790 & 0.000 \\
\hline Trust $\rightarrow$ Repurchase & 0.703 & 0.029 & 0.629 & 0.747 & 24.165 & 0.000 \\
\hline
\end{tabular}

The strength and significance of the estimated values for the path linkages in the structural model (all latent variables) should be assessed. The t-statistic value was utilized to describe the importance of the association between variables, and the significant value was determined using the bootstrapping process. The test criteria used a significance level $(\alpha)=0.05$ and $t$ count $>t$ table.

Based on Table 4, three paths estimated the relationship between the variables. The original sample column shows the path coefficients, and the t-stats column shows the t-statistic results of the measured path to express significance. All path coefficient values are positive (path coefficient $>0$ ), which means a positive influence between the two variables. When viewed in the t-stats column, all $t$-statistical values> $t$ table (1.96) and significance $<0.05$. Therefore, all of the tested hypotheses can be accepted.

Furthermore, to see the magnitude of the influence between variables, refer to the F-Square value (Table 5). Information quality has a weak impact on trust, transaction safety has a moderate effect on trust, and trust strongly influences repurchase intentions. In addition, the structural model produces an R-Square value for the confidence of 0.593 and repurchase of 0.495 . It means that information quality and transaction safety contribute $59.3 \%$ in forming a trust, and repurchase intention is determined by $49.5 \%$ by a trust. Overall, the model has an excellent predictive relevance value because the resulting Q-Square value is $0.790>0$.

Table 5. Effect Size

\begin{tabular}{lccc}
\hline \multicolumn{1}{c}{ Path } & F-Square & Result & R-Square \\
\hline Information Quality $\rightarrow$ Trust & 0.133 & Weak & 0.593 \\
Transaction Safety $\rightarrow$ Trust & 0.302 & Moderate & \\
Trust $\rightarrow$ Repurchase & 0.979 & Strong & 0.495 \\
\hline
\end{tabular}

\section{Conclusion}

This study succeeded in answering all research hypotheses. First, the quality of information has a positive and significant impact on trust. This study demonstrates that it can build customer trust if the e-commerce platform's data quality can assist business people. It indicates that customers are confident that e-commerce provides accurate, reliable, current, timely, complete, and easy-to-understand information.

Companies should consider strategies to increase the appropriateness and utility of the information provided on mobile applications, such as providing users with relevant information and particular instructions for using the app. In addition, the information in the application must be updated regularly, and the service description must be more explicit. To contribute to system quality, mobile applications must be simple to use, navigate, and access (Phuong \& Dai Trang, 2018).

Second, transaction safety has a significant positive impact on trust. According to Abdullah and Saleh (2019), customers value security and privacy features. Customers must feel safe, and their privacy must be protected before engaging in online transactions. When dealing with websites, e-commerce customers are apprehensive about their personal and financial information (Vakeel, Das, Udo, \& Bagchi, 2017). Customers understand the significance of online security in e-commerce, and they consider security and privacy to be factors that influence trust (Abdullah \& Saleh, 2019). It supports a prior study that shows competence is attained when buyers trust the seller's ability to execute sales transactions based on their business knowledge.

Furthermore, perceived integrity happens when the customer believes that the seller is trustworthy and acts sincerely during the transaction without charging excessive fees or failing to follow through on their commitment. Furthermore, customers perceive kindness when they believe the seller acts in their best interests and does everything necessary to help them (Oliveira et al., 2017). It is supported by research by Tam et al. (2020), which explains that customers trust e-commerce if merchants handle transactions with competence and integrity and do their utmost to assist customers with good intentions.

Third, trust has a positive and significant effect on repurchase intention. According to Yeo, Tan, Teo, and Tan (2021), trust is an essential factor in increasing repurchase intention. Consumers will trust the service provider and become loyal customers if they have a positive security experience during the purchasing process. Yang et al. (2019) found that online consumers may find it easier to trust online sellers and make repurchases if they perceive the seller to exhibit good ethical behavior. The research results by Trivedi and Yadav (2018) show that trust is an essential factor in repurchase intentions. Business success needs to understand how to develop trust with potential customers and the trust factors that can influence repurchase decisions. Trust is an essential factor in increasing repurchase intention. 
Finally, this study concludes that information quality and transaction safety positively and significantly impact trust, impacting repurchase intention.

\section{References}

Abdullah, R., \& Saleh, Y. (2019). Factors affecting buyers' trust in e-commerce in Palestine. Middle East Journal of Management, 6(5), 597-639. doi:10.1504/MEJM.2019.101923

Ahmad, S. N., \& Callow, M. (2018). "Free Shipping" or "Dollar Off"? The Moderating Effects of List Price and E-Shopping Experience On Consumer Preference For Online Discount. International Journal of Electronic Commerce Studies, 9(1), 55-70.

Chen, C.-C., \& Chang, Y.-C. (2018). What drives purchase intention on Airbnb? Perspectives of consumer reviews, information quality, and media richness. Telematics and Informatics, 35(5), 1512-1523. doi:https://doi.org/10.1016/j.tele.2018.03.019

Cheung, M. F. Y., \& To, W. M. (2017). The influence of the propensity to trust on mobile users' attitudes toward in-app advertisements: An extension of the theory of planned behavior. Computers in Human Behavior, 76, 102-111. doi:https://doi.org/10.1016/j.chb.2017.07.011

Choi, Y., \& Mai, D. Q. (2018). The Sustainable Role of the E-Trust in the B2C E-Commerce of Vietnam. Sustainability, 10(1). doi:10.3390/su10010291

Dillahunt, T. R., \& Malone, A. R. (2015). The Promise of the Sharing Economy among Disadvantaged Communities. Paper presented at the Proceedings of the 33rd Annual ACM Conference on Human Factors in Computing Systems, Seoul, Republic of Korea. https://doi.org/10.1145/2702123.2702189

Evans, D. S., \& Schmalensee, R. (2016). Matchmakers: The new economics of multisided platforms: Harvard Business Review Press.

Featherman, M. S., \& Hajli, N. (2016). Self-Service Technologies and e-Services Risks in Social Commerce Era. Journal of Business Ethics, 139(2), 251-269. doi:10.1007/s10551-015-2614-4

Ganapati, S., \& Reddick, C. G. (2018). Prospects and challenges of sharing economy for the public sector. Government Information Quarterly, 35(1), 77-87. doi:https://doi.org/10.1016/j.giq.2018.01.001

Hair, J., Hult, G. T. M., Ringle, C., \& Sarstedt, M. (2017). A Primer on Partial Least Squares Structural Equation Modeling (PLS-SEM) (2 ed.). United States of America: SAGE Publications.

Hair, J., William C, B., Barry J, B., \& Rolph E, A. (2019). Multivariate Data Analysis (8 ed.). United Kingdom: Cengage Learning EMEA.

Hansen Henten, A., \& Maria Windekilde, I. (2016). Transaction costs and the sharing economy. INFO, 18(1), 1-15. doi:10.1108/info-09-2015-0044

Henseler, J., Ringle, C. M., \& Sarstedt, M. (2015). A new criterion for assessing discriminant validity in variance-based structural equation modeling. Journal of the Academy of Marketing Science, 43(1), 115135. doi:10.1007/s11747-014-0403-8

Kian, T. P., Loong, A. C. W., \& Fong, S. W. L. (2018). Customer purchase intention on online grocery shopping. International Journal of Academic Research in Business and Social Sciences, 8(12).

Kim, S., \& Park, H. (2013). Effects of social commerce (s-commerce) characteristics on consumers' trust and trust performance. International Journal of Information Management, 33(2), 318-332. doi:https://doi.org/10.1016/j.ijinfomgt.2012.11.006

Kong, Y., Wang, Y., Hajli, S., \& Featherman, M. (2020). In Sharing Economy We Trust: Examining the Effect of Social and Technical Enablers on Millennials' Trust in Sharing Commerce. Computers in Human Behavior, 108, 105993. doi:https://doi.org/10.1016/j.chb.2019.04.017

Lee, S. W., Sung, H. J., \& Jeon, H. M. (2019). Determinants of Continuous Intention on Food Delivery Apps: Extending UTAUT2 with Information Quality. Sustainability, 11(11). doi:10.3390/su11113141

Li, S., \& Lin, B. (2006). Accessing information sharing and information quality in supply chain management. Decision Support Systems, 42(3), 1641-1656. doi:https://doi.org/10.1016/j.dss.2006.02.011

Lim, X.-J., Cheah, J.-H., Waller, D. S., Ting, H., \& Ng, S. I. (2020). What does s-commerce imply? Repurchase intention and its antecedents. Marketing Intelligence \& Planning, 38(6), 760-776. doi:10.1108/MIP-03-2019-0145

Oliveira, T., Alhinho, M., Rita, P., \& Dhillon, G. (2017). Modeling and testing consumer trust dimensions in e-commerce. Computers in Human Behavior, 71, 153-164. doi:https://doi.org/10.1016/j.chb.2017.01.050

Pauzi, S. F. F., Thoo, A. C., Tan, L. C., Muharam, F. M., \& Talib, N. A. (2017). Factors Influencing Consumers Intention for Online Grocery Shopping - A Proposed Framework. IOP Conference Series: Materials Science and Engineering, 215, 012013. doi:10.1088/1757-899x/215/1/012013

Phuong, N. N. D., \& Dai Trang, T. T. (2018). Repurchase intention: The effect of service quality, system quality, information quality, and customer satisfaction as mediating role: a PLS approach of m-commerce ride-hailing service in Vietnam. Marketing and Branding Research, 5(2), 78.

Ranganathan, C., \& Ganapathy, S. (2002). Key dimensions of business-to-consumer websites. Information \& Management, 39(6), 457-465. doi:https://doi.org/10.1016/S0378-7206(01)00112-4

Ringle, C. M., Wende, S., \& Becker, J.-M. (2015). SmartPLS 3. Retrieved from http://www.smartpls.com. 
Skordoulis, M., Kaskouta, I., Chalikias, M., \& Drosos, D. (2018). E-commerce and e-customer satisfaction during the economic crisis. Journal for International Business and Entrepreneurship Development, 11(1), 15-29. doi:10.1504/JIBED.2018.090018

Tam, C., Loureiro, A., \& Oliveira, T. (2020). The individual performance outcome behind e-commerce. Internet Research, 30(2), 439-462. doi:10.1108/INTR-06-2018-0262

Trivedi, S. K., \& Yadav, M. (2018). Predicting online repurchase intentions with e-satisfaction as mediator: a study on Gen Y. VINE Journal of Information and Knowledge Management Systems, 48(3), 427-447. doi:10.1108/VJIKMS-10-2017-0066

Vakeel, K. A., Das, S., Udo, G. J., \& Bagchi, K. (2017). Do security and privacy policies in B2B and B2C ecommerce differ? A comparative study using content analysis. Behaviour \& Information Technology, 36(4), 390-403. doi:10.1080/0144929X.2016.1236837

Wang, E. S.-T., \& Chu, Y.-H. (2020). Influence of Consumer's Long-term Orientation and Safety Consciousness on Intention to Repurchase Certified Functional Foods. Journal of Food Products Marketing, 26(4), 247-261. doi:10.1080/10454446.2020.1757554

Yang, Z., Van Ngo, Q., Chen, Y., Nguyen, C. X.-T., \& Hoang, H. T. (2019). Does Ethics Perception Foster Consumer Repurchase Intention? Role of Trust, Perceived Uncertainty, and Shopping Habit. SAGE Open, 9(2), 2158244019848844. doi:10.1177/2158244019848844

Yeo, S. F., Tan, C. L., Teo, S. L., \& Tan, K. H. (2021). The role of food apps servitization on repurchase intention: A study of FoodPanda. International Journal of Production Economics, 234, 108063. doi:https://doi.org/10.1016/j.ijpe.2021.108063

Zhao, H. (2019). Information Quality or Entities' Interactivity? Understanding the Determinants of Social Network-Based Brand Community Participation. Future Internet, 11(4). doi:10.3390/fi11040087

Zhu, W., Mou, J., \& Benyoucef, M. (2019). Exploring purchase intention in cross-border E-commerce: A three-stage model. Journal of Retailing and Consumer Services, 51, 320-330. doi:https://doi.org/10.1016/j.jretconser.2019.07.004 